\title{
Lower Ordovician graptolite fauna of the Bogo Shale (West Norway), and its palaeogeographical relationships
}

\author{
OLAF SCHMIDT
}

\begin{abstract}
Schmidt, O.: Lower Ordovician graptolite fauna of the Bogo Shale (West Norway), and its paloegeographical relationships. Bull. geol. Soc. Denmark, vol. 35, pp. 209-215, Copenhagen, July 1st, 1987. https://doi.org/10.37570/bgsd-1986-35-22

Recent collections of some 1500 slabs in the Bogo Shale yielded 29 different graptolite species indicating an age of latest Arenig (upper $D$. hirundo biozone). Comparison with graptolites of the same age from we-stern Newfoundland showed a high species similarity. Both of the faunas appear to represent the Pacific graptolite province. However, recent reports about short-distance variations in isochronal faunal associa-tions and mixed (Atlantic/Pacific) faunas confirm that the hypothesis of graptolite faunal provincialism de-serves a critical review invoking alternative controls such as bathymetric thermocline and chemocline vari-ations.
\end{abstract}

O. Schmidt, Institut für Geologie und Paläontologie, TU Berlin, Hardenbergstr. 42, D-1000 Berlin 42, Fe-deral Republik of Germany, August 30th, 1985.

\section{Introduction}

The Bogo Shale fauna has not yet been fully described and analyzed since its discovery by Blake in 1960. The sites are located in an area roughly $50 \mathrm{~km}$ southwest of Trondheim. In 1982 and 1983 this area was mapped and the graptolite fauna described (Schmidt 1984, 1985).

The Bogo area is part of the Caledonide orogen, the basement of which is formed by Precambrian magmatites, gneisses, and metasediments (Gee 1975: 469) and is generally considered to be autochthonous. On the contrary, the Lower Paleozoic units, consisting of (meta-) sediments, volcanic rocks and metamorphites, are thought to be allochthonous. They originate (north-)west of the present-day Scandinavian Atlantic coast and were thrusted on to the Baltic Shield parallel to the closure of the proto-Atlantic ocean, the lapetus (Wilson 1966, Harland \& Gayer 1972) within the Ordovician to midSilurian time. Evidence for the allochthonous character are (1) rapid changes of metamorphic facies, (2) the juxtaposition of (a) highly deformed and almost undeformed rocks (Gee 1975: 492-493) and (b) Eocambrian arkoses and oceanfloor basalt (Gale \& Roberts 1974: 384-385). The estimates of the nappe transport distances are between $200 \mathrm{~km}$ (Gale \& Roberts 1974: 386) and more than $500 \mathrm{~km}$ (Gee 1975: 495). These allochthonous sequences are divided into an east- ern ("eugeosynclinal") and a western ("miogeosynclinal") complex (Gee 1975: 472 \& 489 and table 1, Wolff 1980: 119 and table 1).

Two of the groups of the "western" Trondheim Supergroup are of interest for this paper: the Støren Group (Tremadoc - Arenig), primarily consisting of metabasalts, and the sedimentary Lower Hovin Group (Arenig - Caradoc) which includes the Bogo Shale. Facies interpretations mainly depend on the assignment of the underlying greenstones of the Støren Group. Some authors suggest that the Støren greenstones represent ocean-floor basalt (Furnes, Roberts, Sturt, Thon \& Gale 1980). Others prefer a combination of ocean-floor basalt and low- $\mathrm{K}$ tholeiites of island-arc type. Accordingly, the Lower Hovin Group strata are regarded as back-arc marginal basin sediments or as a "heterogeneic" sequence connected with volcanism (Grenne, Grammeltvedt \& Vokes 1980). Another study takes the view that all the greenstones developed from an island-arc system (Loeschke 1976a, 1976b 1980). We may sum up by saying the origins of both of the groups are still under discussion as is their paleogeographic position: suggesting an islandarc system for the Lower Hovin Group the Bogo Shale is placed at the Baltoscandian (Gale \& Roberts 1974, Furnes et al. 1980) or at the Laurentian side (Horne 1979, Burton \& Bockelie 1980) of the lapetus.

The Bogo Shale consists of a series of blue- 
Table 1. Faunal list of the Bogo Shale graptolites. Explanation for the nos. 1-3 see text. Crosses mark the forms which have been discovered in Newfoundland. $(a=$ abundant, $c=$ common, $\mathrm{r}=$ rare, $\mathrm{rr}=$ very rare).

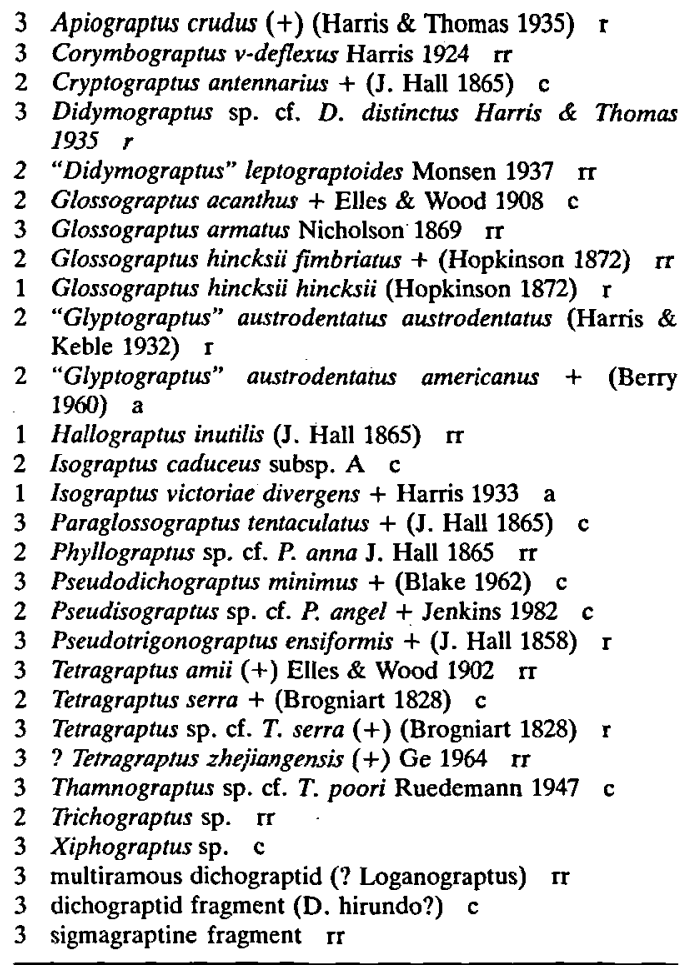

grey to dark grey pyritic shales with thin silt and sandstone beds ( $\mathrm{mm}$ to $\mathrm{cm}$ scale), carbonate layers and breccias. Its thickness can only be estimated by the limited outcrops: it probably amounts to ca. $40 \mathrm{~m}$. The section at locality "Bogo 1" (see Blake 1962: 225, fig. 1) is $5 \mathrm{~m}$ thick and at "Bogo 2" about $9 \mathrm{~m}$. The remaining fossilbearing localities "Bogo 3, 4", and " 5 " have insignificant thicknesses or represent merely incomplete sections.

In 1960 Blake discovered the Bogo Shale by carrying out the first detailed mapping of this area. Two years later he published a faunal list comprising almost exclusively of graptolites
(Blake 1962: 236-237). From his collection of 17 different species he derived an age of mid-Arenig (Phyllograptus densus zone, ibid.: 235-236), however, his reference to Spjeldnaes (1953) is incorrect as the section described by him is of uppermost Arenig age (Spjeldnaes 1953: 182-183). Blake conceded later that the Bogo Shale may be younger (Chadwick, Blake, Beswick \& Rowling 1963: 52). The initial dating was challenged by Skevington who contended that the only conclusive age which may be determined by Blake's collection is the Didymograptus hirundo biozone (Skevington 1963: 259). Nevertheless, the literature contains many references upholding Blake's original assignation (e.g., Strand \& Kulling 1972: 54).

A few years later Berry reexamined the Bogo material stored at the Paleontological Museum in Oslo and published a list of graptolites without descriptions (Berry 1968: 218). In his opinion the fauna indicates an age correlative to the North American graptolite zones 8 (Isograptus) and 9 (Paraglossagraptus etheridgei) which are, respectively, late Arenig and Llanvirn. Due to the relative sparseness of fossiliferous strata in the Trondheim region the Bogo Shale plays an important role in dating orogenic events and nappe transport in this part of the Caledonides (e.g. Berry 1968: 225 ff., Dewey, Rickards \& Skevington 1970).

\section{Age and Correlation}

My task was to determine the stratigraphic ranges of the Bogo graptolites. For this purpose the existing collections of the Paleontological Museum in Oslo, that of Prof. N. Spjeldnaes and my own collection were investigated. The graptolite specimens are flat. Only a few are preserved threedimensionally filled in with pyrite. The investigations yielded 29 different graptolites (see table 1, the nos. 1-3 refer to the remarks below, and fig. 1). Comparing table 1 to the faunal lists

Fig. 1. The most important and the most common graptolites of the Bogo Shale fauna.

\footnotetext{
A "Glyptograptus" austrodentatus austrodentatus (Berry 1960) PMO 113.781

B Pseudisograptus sp. cf. P. angel Jenkins 1982 PMO 113.783

C Apiograptus crudus (Harris \& Thomas 1935) PMO 113.788

D Paraglossograptus tentaculatus (J. Hall 1865) PMO 113.784

E Isograptus victoriae divergens Harris 1933 PMO 113.785

F Isograptus caduceus subsp. A PMO 113.786
}

G Xiphograptus sp. PMO 113.790

H Cryptograptus antennarius (J. Hall 1865) PMO 113.789

I Tetragraptus serra (Brongniart 1828) PMO 113.792

J Pseudotrigonograptus ensiformis (J. Hall 1858) PMO 113.787

K Pseudodichograptus minimus (Blake 1962) PMO 113.794

L Glossograptus acanthus Elles \& Wood 1908 PMO 113.791 Each bar indicates $1 \mathrm{~mm}$. 


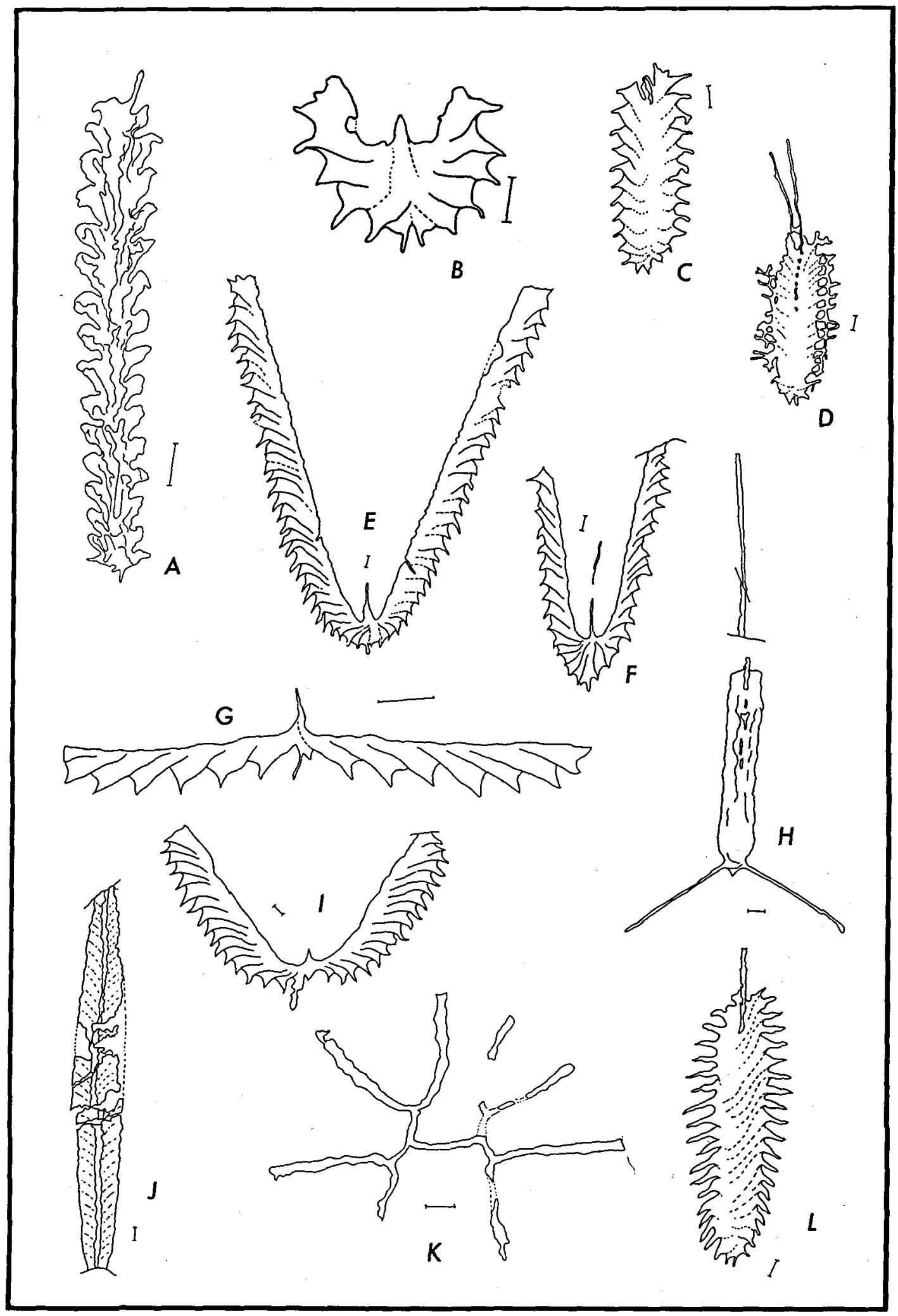

I4 D.G.F. 35 
of Blake (1962) and Berry (1968) the following results became obvious:

1) There are only three species common to each of the lists

2) eleven forms have been assigned to different species or have not been discovered by either of the authors

3) fifteen species have been described from the Bogo Shale for the first time by this author (Schmidt 1984, 1985 and unpublished data).

Besides some rare forms, genera/species like Paraglossograptus, Isograptus caduceus, Pseudisograptus, Apiograptus and Thamnograptus belong to the last group. Considering the stratigraphic ranges of all occurring species, it can only be stated that the Bogo Shale is correlative to the upper part of the $D$. hirundo biozone which more or less confirms Skevington's assumption. Resorting to the Australian graptolite zonation did not prove to be more successful: there are stratigraphic discrepancies as some Bogo species are Yapeenian (or older, e.g., Isograptus caduceus), whilst some only make their first appearance in the Darriwillian of Australasia (Cryptograptus, "Glyptograptus", Paraglossograptus). They are found, however, on the same slab (e.g. PMO 113. 795 with Cryptograptus antennarius and Isograptus caduceus subsp. A). From Scania, Nilsson (1984: 263, fig. 2) recorded " $I$. imitatus" from the same horizon as where "Glyptograptus austrodentatus austrodentatus" occurs. Therefore, the stratigraphic range of Isograptus caduceus extends to the Darriwillian. C. antennarius is a typical graptolite of the Llanvirn, but according to Berry (1962: 702-704, table 1) it already occurs in $\mathrm{Da} 1$. The exact assignment of Thamnograptus is impossible not only due to the preliminary identification on generic level, but also to the fact that all previous records of Thamnograptus have been recorded in the Upper Ordovician (Llandeilo/Caradoc) or even younger horizons (Ruedemann 1947; Finney 1980). "Didymograptus" leptograptoides (quotation marks are for the disputed generic assignment, see Finney \& Branisa 1984: 360) and Trichograptus are added from Blake's list provisionally, they have not been discovered by the author. Da 1 is a suitable date for the age of the Bogo Shale in terms of Australian graptolite zonation, which is equivalent to the upper $D$. hirundo biozone.
The attempt at correlating the Bogo Shale with fossiliferous strata in Scandinavia has proved difficult: the Tøyen Shale (former Lower Didymograptus Shale) is too old, although its top is of the D. hirundo age (Erdtmann 1965: 538-539, textfix. 12). In the Andersö Shale (former Ogygiocaris Shale) and the "Upper Didymograptus" Shale Glossograptus hincksii hincksii (Berry 1964: 74-75, table 1, Ekström 1937: 40, pl. VIII, fig. 9) is the only form being common with the Bogo Shale. The Gausdal phyllites include the stratigraphic range of the Bogo Shale (Ch $2-\mathrm{Da} 2$, Williams 1984: 10) but from this recently reviewed fauna only Phyllograptus anna and "Glyptograptus" spp., which closely resembles the Bogo specimens of "Gl." austrodentatus americanus, agree with the Bogo fauna. The "Whiterockian" Hølonda Limestone, the fossil locality closest to the Bogo Shale, as well as the Komstad Limestone (former Orthoceras Limestone) and other carbonates of similar age do not contain any graptolite faunas. Portions of a drillcore from Scania have several species in common with the Bogo Shale (Nilsson 1984, fig. 2).

In Jenkins' recent (1982) work on the isograptids of England and Wales, Isograptus victoriae divergens is in accordance with the Bogo fauna. Only one pseudisograptid species ( $P$. cf. angel) appears to coincide with the Bogo specimens but it is interesting to note that the British forms share the same feature having an "unusually low profile to the manubrium... and may represent a completely independent line..." (Jenkins 1982: 241). Also Jenkins correlated the Bogo Shale with the $D$. hirundo biozone.

\section{Faunal Provincialism}

The Bogo graptolites appear to reveal a greater Pacific affinity in the sense of graptolite faunal provincialism. This is supported by recent discoveries in penecontemporaneous graptolitic strata of western Newfoundland: graptolites from the uppermost part of the Cow Head Group at Western Brook Pond (pers, obs. 1984, Williams \& Stevens in prep.) show a high similarity at species level with those from the Bogo Shale (table 1 , common forms are marked with a cross). It is conspicuous that many of the species as yet undiscovered in Newfoundland only seldom appear 
in the Bogo Shale. This could, however, be put down to the fact that so few specimens have been collected in Canada. The common forms clearly show Pacific affinities. Compared to Skevington's list (1973: 32) of genera which are characteristic for the Pacific and Atlantic provinces it readily appears that, concerning the Arenig, no endemic Atlantic species but several prevailing ones exist in the Bogo Shale. Isograptus is the only endemic genus of Pacific type in Bogo, the very characteristic Oncograptus, Cardiograptus and Skiagraptus are not to be found. In Llanvirn time the Atlantic fauna is characterized merely by the massive appearance of pendent didymograptids (Skevington 1973: 32, 1974: 69). The endemically Pacific genera being present in the Bogo Shale are Paraglossograptus and Apiograptus. They occur together with the pandemic Hallograptus, Cryptograptus and Glossograptus.

Thus, the Bogo Shale is considered to belong to the Pacific graptolite province (e.g., Skevington 1974: 59) and this is in agreement with the brachiopod/trilobite fauna of the North American type found in the adjacent Smøla and Hølonda localities (Neuman \& Bruton 1974, Bruton \& Bockelie 1979). Therefore, Bruton \& Bockelie concluded (1980, figs. $6 \& 7$ ) the position of the Trondheim region to be much closer to the Laurentian than to the Baltic Shield along a NW directed subduction zone. A similar paleogeographic position was proposed by Whittington \& Hughes (1972, fig. 3).

\section{Paleobiography}

Numerous papers deal with graptolite faunal provincialism and its possible origin yet only few ones can be cited here. According to Bulman (1964: 71) water temperature is the determining factor. Skevington (1974: 62, text-fig. 1; 1978: 22, text-fig. 1) presented a model in which Pacific graptolites occupy the area between $30^{\circ} \mathrm{N}$ and $30^{\circ} \mathrm{S}$ of the paleoequator with Atlantic forms confined to the presumably cooler waters of higher latitudes. Berry \& Boucot (1972) and Erdtmann (1976) emphasized the bathymetry to explain the difference of graptolite assemblages and this idea has been taken up by others (Kaljo 1978; Cisne \& Chandlee 1982). Lenz \& Chen (1985) give a short summary of graptolite provincialism discussions and they point out a possible relationship between lithofacies and graptolite distribution, citing several cases of isochronous, different graptolite faunas with the same sedimentary basin. They (Lenz \& Chen 1985: 640) believe the depth of water column to play an important role, although they admit that the practical reasons responsible for faunal provincialism are as yet unknown.

One of the cases cited in that paper is the Athens Shale of Alabama where two graptolite faunas, ca. $70 \mathrm{~km}$ apart during the Ordovician, show a remarkable degree of difference in their species assemblage (Finney 1984). Finney explained that water mass specificity was the main cause for this faunal differentiation.

Fortey presents a comprehensive and convincing model based on the idea that trans- and regressions, combined with evolutionary developments, are responsible for graptolite faunal changes during the Ordovician (Fortey 1984: 37, figs. 3-5). During the Arenig transgression the pendent didymograptids in the equatorial regions and Azygograptus and Corymbograptus at high latitudes form restricted epiplanktonic graptolite faunas. On the other hand, there is an oceanic "isograptid biofacies" with a rich fauna - characterized by Isograptus, Pseudisograptus, sigmagraptines and probably Pseudotrigonograptus which is independent of geographic barriers (ibid.: 42, fig. 6).

The Late Arenig is a regressive phase and, according to Fortey, island sites may be important to the development of graptolite faunas during the ensuing transgressions. This is the case when the Llanvirn transgression brings the "isograptid biofacies" to the edge of the North American craton (ibid.: 40, 48 and fig. 7).

The Bogo Shale graptolites clearly represent the "isograptid biofacies" and may well be explained as being an island fauna in the sense of Fortey's model. Therefore, this fauna cannot serve as an example for paleogeographic reconstructions.

The author does not intend to reject the concept of faunal provincialism as a whole but to give testimony to our current state of ignorance regarding its mechanism. This mechanism probably is an interplay of several factors such as temperature, depth, salinity, vacillating chemoclines, which complicate reaching paleographic conclu- 
sions. Skevington has already warned (1978: 25) of deducing palaeogeographic positions from the aspect of faunal provincialism as it cannot be taken as evidence for spatial separation per se. The objections are as follows: the lapetus - if it had ever been a physical barrier for graptolites at all - commenced closing long before the graptolite faunal provincialism reached its maximum (instead of logically reflecting the closure by showing a decrease) (Skevington 1978: 25). Secondly, there is no sharp boundary between Atlantic and Pacific faunas (Skevington 1973: 28) but there are mixed graptolite faunas similar to that reviewed from the Lovisefred core in Scania (Nilsson 1984). This fauna bears Azygograptus Kinnegraptus, and Maeandrograptus - three endemic forms of the Atlantic province (Skevington 1973: 32) - together with seven (sub-)species of Isograptus, Pseudisograptus, Skiagraptus and Apiograptus (Nilsson 1984: 263, fig. 2), which are typical for Pacific graptolite assemblages.

Erdtmann (1984: 12) suggests a "Gulf Stream effect", i.e. thermocline related water mass movements, which enables graptolites (and larvae of tribolites and gastropods?) to overcome the oceanic distances. This was demonstrated in the case of the "teleplanic larvae" of recent gastropods being transported by ocean currents from the west Atlantic coast to Northern and tropic Atlantic regions: six species are in a position to delay the point of settlement long enough (Scheltema 1971). Newell (1971: 22-23) reported corals which migrate from the African east coast to North and South American coasts, i.e. over distances of more than $10,000 \mathrm{~km}$. Tertiary and recent bryozoans also show circumoceanic distribution patterns (Lagaij \& Cook 1973, figs. 1-4).

It should not be forgotten to mention that, from a geochemical and sedimentary point of view, several studies place the origin of the Trondheim region close to the Baltoscandian Shield (e.g. Gale \& Roberts 1974, fig. 4). By applying all geologic aspects, of course, it may be possible to find the source of graptolite provincialism. With a back-arc marginal basin as the origin of the Bogo Shale, it would not at all be surprising to find a fauna being markedly different from (present-day) adjacent faunas in Scandinavia. The question of the exact paleogeographic position cannot be answered at present.
Acknowledgements. I wish to thank B.-D. Erdtmann for having supervised the Bogo Shale graduate thesis and for having reviewed and discussed this manuscript. Further Dr. D. L. Bruton, Paleontologisk Museum i Oslo, for financial support and the loan of the PMO-collection, and the Orkla Aktiebolag at Løkken for making free accomodation and scientific material available to me during field work in Norway. Unpublished data from S. H. Williams, N. P. James and R. K. Stevens (Memorial University of Newfoundland) are gratefully acknowledged.

\section{Dansk sammendrag}

Nylige indsamlinger af omkring 1500 stykker fra Bogo Skiferen har ydet 29 forskellige graptolit-arter, hvis alder ansættes til $\emptyset$ verste Arenig ( $\varnothing v r e$ del af $D$. hirundo biozonen). En sammenligning med graptoliter af samme alder fra det vestlige Newfoundland viste en høj grad af arts-lighed. Begge faunaer synes at repræsentere den pacifiske graptolit-provins.

Nyere studier over variationer over korte afstand inden for samtidige faunaselskaber, også hvor disse er blandet (dvs. atlantiske og pacifiske), synes at bekrafte den hypothese, at der findes provinsialisme inden for graptolit faunaer, og at dette fordrer en kritisk gennemgang med hensyntagen til faktorer såsom termogradienter og kemiske forskelligheder $i$ fortidens have.

\section{References}

Berry, W. B. N. 1962: Stratigraphy, zonation, and age of Schaghticoke, Deepkill and Normanskill Shales, Eastern New York. Geol. Soc. Amer. Bull. 73, 695-718.

Berry, W. B. N. 1964: The Middle Ordovician of the Oslo region, Norway: 16. Graptolites of the Ogygiocaris series. Norsk Geol. Tidskr. 44, 61-170.

Berry, W. B. N. 1968: Age of Bogo Shale and western Ireland graptolite faunas and their bearing on dating early Ordovician deformation and metamorphism in Norway and Britain. Norsk Geol. Tidsskr. 48, 217-230.

Berry, W. B. N. \& Boucot, A. J. 1972: Silurian graptolite depth zonation. 24th Intern. Geol. Congr., Montreal 1972, section 7, 59-65.

Blake, D. H. 1962: A new Lower Ordovician graptolite fauna from the Trondheim region. Norsk Geol. Tidsskr. 42, 223238.

Bruton, D. L. \& Bockelie, J.F. 1979: The Ordovician sedjmentary sequence on Smøla, West Central Norway. Norges Geol. Unders. 348, 21-31.

Bruton, D. L. \& Bockelie, J. F. 1980: Geology and paleontology of the Hølonda area, western Norway - A fragment of North America? Dept. Geol. Sci. Va. Inst. \& State Univ. Mem. 2, 41-47.

Bulman, O. M. B. 1964: Lower Paleozoic plankton. Quart. J. Geol. Soc. London 120, 455-476.

Chadwick, B., Blake, D. H., Beswick, A. E. \& Rowling, J. W. 1963: The geology of the Fjeldheim - Gassbakken area, Sør-Trøndelag. Norges Geol. Unders. 223, 43-60.

Cisne, J. L. \& Chandlee, G. O. 1982: Taconic foreland basin graptolites: age, depth zonation, and use in ecostratigraphic correlation. Lethaia $15,343-363$.

Dewey, J. F., Rickards, R. B. \& Skevington, D. 1970: New light on the age of Dalradian deformation and metamorphism in western Ireland. Norsk Geol. Tidsskr. 50, 19-40.

Ekström, G. 1937: Upper Didymograptus Shale in Scania. Sveriges Geol. Unders. Afhandl., ser. C 403: 1-53. 
Erdtmann, B.-D. 1965: Outline stratigraphy of graptolite-bearing 3b (Lower Ordovician) strata in the Oslo region, Norway. Investigations of a section at Toyen, Oslo. Norsk Geol. Tidsskr. 45, 481-547.

Erdtmann, B.-D. 1976: Ecostratigraphy of Ordovician graptolites. In: Bassett, M. G. (ed.): The Ordovician System: Proceedings of a Paleontological Association Symposium, Birmingham, Sept. 1974, Univ. Wales Press and Nat. Mus. of Wales, Cardiff: 621-643.

Erdtmann, B.-D. 1984: Outline ecostratigraphic analysis of the Ordovician graptolite zones in Scandinavia in relation to the paleogeographic disposition of the lapetus. Geol. et Paleont. 18, 9-15.

Finney, S. C. 1980: Thamnograptid, dichograptid, and abrograptid graptolites from the Middle Ordovician Athens Shale of Alabama. J. Paleont 54, 1184-1208.

Finney, S. C. 1984: Biogeography of Ordovician graptolites in the southern Appalachians. In: Bruton, D. L. (ed.): Aspects of the Ordovician System. Palaeont. Contrib. Univ. Oslo 295, 167-176.

Finney, S. C. \& Branisa, L. 1984: Two new Ordovician graptolites from Bolivia. Geol. Mag. 121, 357-366.

Fortey, R. A. 1984: Global earlier Ordovician transgressions and regressions and their biological implications. In: Bruton, D. L.: Aspects of the Ordovician System. Palaeont. Contrib. Univ. Oslo 295, 37-50.

Furnes, H., Roberts, D., Sturt, B. A., Thon, A. \& Gale, G. H. 1980: Ophiolite fragments in the Scandinavian Caledonides. In: Panayiotou, A. (ed.): Ophiolites. Proc. Interm. Ophiolite Symp., Cyprus: 582-600.

Gale, G. H. \& Roberts, D. 1974: Trace element geochemistry of Norwegian Lower Paleozoic basic volcanic and its tectonic implications. Earth Planet. Sci. Lett. 22: 380-390.

Gee, D. G. 1975: A tectonic model for the central part of the Scandinavian Caledonides. Amer. J. Sci. 275A, 468-515.

Grenne, T., Grammeltvedt, G. \& Vokes, F. M. 1980: Cyprustype sulphide deposits in the western Trondheim district, central Norwegian Caledonides. In: Panayiotou, A. (ed.): Ophiolites. Proc. Intern. Ophiolite Symp., Cyprus: 727743.

Harland, W. B. \& Gayer, R. A. 1972: The arctic Caledonides and earlier oceans. Geol. Mag. 109, 289-314.

Jenkins, C. J. 1982: Isograptus gibberulus (Nicholson) and the isograptids of the Arenig series (Ordovician) of England and Wales. Proc. Yorkshire Geol. Soc. 44, 219-248.

Horne, G. S. 1979: Mélange in the Trondheim nappe suggests a new tectonic model for central Norwegian Caledonides. Nature 281, 267-270.

Kaljo, D. L. 1978: On the bathymetric distribution of graptolites. Acta Palaeont. Polonica 23, 523-529.

Lagaaij, R. \& Cook, P. L. 1973: Some Tertiary to recent bryozoa. In: Hallam, A. (ed.): Atlas of Paleobiogeography, Elsevier, Amsterdam: 489-498.

Lenz, A. C. \& Chen, X. 1985: Graptolite distribution and lithofacies: some case histories. J. Paleont. 59, 636-642.

Loeschke, J. 1976a: Major element variations in Ordovician pillow lavas of the Støren Group, Trondheim region (Norway). Norsk Geol. Tidsskr. 56: 141-159.

Loeschke, J. 1976b: Petrochemistry of eugeosynclinal magmatic rocks of the area around Trondheim (Central Norwegian Caledonides). N. Jb. Miner. Abh. 128, 41-72.
Loeschke, J. 1980: Antwort: Gehalte Seltener Erden in norwegischen Grünsteinen und ihre Bedeutung für geotektonische Interpretationen. Norsk Geol. Tidsskr. 60, 207212.

Neuman, R. B. \& Bruton, D. L. 1974: Early Middle Ordovician fossils from the Hølonda area, Trondheim region, Norway. Norsk Geol. Tidsskr. 54, 69-115.

Newell, N.D. 1971: An outline history of tropical organic reefs. Amer. Mus. Novitates 2465, 1-37.

Nilsson, R. 1984: The Didymograptus hirundo and Akidograptus ascensus zones of the Lovisefred core, NW Scania, South Sweden. Geol. Fören. i Stockholm Förhandl. 105, 261-267.

Ruedemann, R. 1947: Graptolites of North America. Geol. Soc. Amer. Mem. 19, 1-652.

Scheltema, R. S. 1971: The dispersals of the larvae of shallowwater benthic invertebrates over long distances by ocean currents. Proc. 4th Intern. Europ. Symp. Marine Biol.: 7-28.

Schmidt, O. 1984: The graptolitic facies of the Bogo Shale (Arenig-Llanvirn), Sør-Trøndelag, west central Norway. Geol. et Palaeont. 18, 17-19.

Schmidt, O. 1985: Die Geologie des Frilsjøen-Svartvatnet-Gebietes und die Graptolithenfauna des Bogo-Schiefers, SørTrøndelag, West-Norwegen (BI. 1521 II, Hølonda, 1: $50000)$. Unpubl. Graduate thesis, Inst. Mus., Geol. Paläont. Univ. Göttingen, 185 pp.

Skevington, D. 1963: A Note on the Age of the Bogo Shale. Norsk Geol. Tidsskr. 43: 257-260.

Skevington, D. 1973: Ordovician Graptolites. In: Hallam, A. (ed.): Atlas of Paleobiogeography. Elsevier, Amsterdam: 27-35.

Skevington, D. 1974: Controls influencing the composition and distribution of Ordovician graptolite faunal provinces. In: Rickards, R. B., Jackson, D. E. \& Hughes, C. P. (eds.): Graptolite studies in honour of O.M. B. Bulman, Spec. Pap. Paleont. 13, 59-73.

Skevington, D. 1978: Latitudinal surface water temperature gradients and Ordovician faunal provinces. Alcheringa 2, 21-26.

Spjeldnaes, N. 1953: The Middle Ordovician of the Oslo region, Norway. 3. Graptolites dating the beds below the Middle Ordovician. Norsk Geol. Tidsskr. 31, 171-184.

Strand, T. \& Kulling, O. 1972: Scandinavian Caledonides. Wiley Intersc., London, New York, Sydney, Toronto, 302 pp.

Whittington, H. B. \& Hughes, C. P. 1972: Ordovician geography and faunal provinces deduced from trilobite distribution. Philos. Trans. Roy. Soc. London B-263, 235-278.

Williams, S. H. 1984: Lower Ordovician graptolites from Gausdal, central southern Norway: a reassessment of the fauna. Norges Geol. Unders. Bull. 395, 1-23.

Williams, S. H. \& Stevens, R. K. (in prep.): Arenig graptolites of the Cow Head Group, western Newfoundland.

Wilson, J. T. 1966: Did the Atlantic close and then re-open? Nature 211, 676-681.

Wolff, F. C. (1980, ed.): Excursions across parts of the Trondheim region, central Norwegian Caledonides. Norges Geol. Unders. 356, 115-167. 